\title{
HUBUNGAN PENGETAHUAN, SIKAP DAN KETERSEDIAAN FASILITAS DENGAN PRAKTIK PETUGAS PENGUMPUL LIMBAH MEDIS DI RUMAH SAKIT UMUM CUT MEUTIA KABUPATEN ACEH UTARA TAHUN 2015
}

\author{
Elfrida Santy Purba ${ }^{1}$ Cut Khairunnisa ${ }^{2 *}$ \\ ${ }^{1}$ Mahasiswa Fakultas Kedokteran Universitas Malikussaleh \\ 2Bagian Ilmu Kesehatan Masyarakat Fakultas Kedokteran Universitas Malikussaleh \\ Jln. H.Meunasah Uteunkot Cunda Lhokseumawe, 24352 \\ ${ }^{*}$ Corresponding Author :icut_nisa@yahoo.com
}

\begin{abstract}
Abstrak
Rumah Sakit merupakan sebuah industri jasa yang memberikan pelayanan kepada masyarakat, dalam pelaksanaan pelayanan, Rumah Sakit dapat memberikan dampak positif dan negatif kepada masyarakat dan lingkungannya.Dampak negatif berupa adanya limbah medis yang dihasilkan.Limbah medis merupakan bahan yang memerlukan penanganan yang baik.Pengelolaan limbah medis harus sesuai prosedur tetap.Namun, dalam praktiknya pengelolaan limbah medis kurang mendapat perhatian dan kurang menjalankan sesuai prosedur tetap yang ada sehingga dapat menjadi kontribusi sumber penyebaran kuman di RSU Cut Meutia.Penelitian ini bertujuan untuk mengetahui adanya hubungan pengetahuan, sikap dan ketersediaan fasilitas dengan praktik petugas pengumpul limbah medis.Penelitian ini merupakan penelitian yang bersifat deskriptif analitik dengan pendekatan cross sectional study. Sampel penelitian adalah 35 petugas pengumpul limbah medis dengan metode total sampling. Pengambilan data menggunakan kuesioner.Analisa data dilakukan secara univariat dan bivariat berupa uji chisquare.Hasil penelitian menunjukkan $\mathrm{p}$ value $>\mathrm{a}$ artinya tidak ada hubungan antara pengetahuan, sikap dan ketersediaan fasilitas dengan praktik petugas pengumpul limbah medis.
\end{abstract}

Kata kunci : Pengetahuan, Sikap, Praktik Petugas 


\title{
RELATIONSHIP OF KNOWLEDGE, ATTITUDE AND THE AVAILABILITY OF FACILITIES WITH THE PRACTICE OF MEDICAL WASTECOLLECTOR INCUT MEUTIA HOSPITAL ACEH UTARA DISTRICT IN 2015
}

\begin{abstract}
Hospital is a service industry that provides services to the community, the Hospital can provide positive and negative effects to society and the environment. The negative impact is medical waste. Medical waste is a material that requires the good handling. The management ofmedical waste should be based on procedure. However, the practice ofmanagement medical waste got less attention and did not based on procedure sothe medical waste can be the sourse of dernal spreading in hospital. This studyaims to investigate the relationship between knowledge, attitude, and facilitiesprovide with the practice of medical waste collection workers. This study is adescriptive analytic research with cross Sectional Study. The study populationwas all the officer collecting medical waste in hospitals Cut Meutia with a totalnumber of 35 people by sampling. Retrieval of data using questionnaires. Dataanalysis was done using univariate and bivariate a chi-square. The result of thestudy test showed $p$ value $>a$ that there isn't relationship between knowledge,attitude and facilities provide with the practice of medical waste collectionworkers.
\end{abstract}

Keywords : Knowledge, Attitude, Practice Officer 


\section{PENDAHULUAN}

Rumah Sakit sebagai sebuah industri jasa yang memberikan pelayanan kesehatan kepada masyarakat, dalam pelaksanaan operasionalnya dapat menimbul dampak negatif baik terhadap lingkungan maupun manusia yang berhubungan dengan limbah medis yang dihasilkan. ${ }^{1}$ Menurut Keputusan Menteri Kesehatan RI.Nomor :1204/Menkes/SK/ X/2004 Tentang Persyaratan Kesehatan Lingkungan Rumah Sakit menyatakan bahwa rumah sakit merupakan tempat berkumpulnya orang sakit maupun orang sehat sehingga dapat menjadi tempat penularan penyakit serta memungkinkan terjadinya pencemaran lingkungan dan gangguan kesehatan. ${ }^{2}$

Untuk mencegah risiko dan gangguan kesehatan bagi lingkungan dan manusia diperlukan penyelenggaraan kesehatan lingkungan rumah sakit. Penanganan limbah rumah sakit merupakan salah satu pencegahan tersebut. Penanganan limbah perlu diperhatikan, karena limbah yangmengandung bahan berbahaya dan/atau beracun yang karena sifat dan/ataukonsentrasinya, baik secara langsung maupun tidak langsung dapat merusak dan/atau mencemarkan lingkungan hidup dan/atau membahayakan kesehatan manusia apabila pengelolaan limbahnya tidak dikelola dengan baik sesuai dengan prinsip-prinsip pengelolaan lingkungan secara menyeluruh. ${ }^{3}$ Penanganan limbah yang tidak sesuai dengan Kepmenkes RI No. 1204 tahun 2004, misalnya tidak dilakukan pemisahan antara limbah medis dengan non medis, tempat penampungan sampah di masing-masing ruangan tidak memenuhi standar, petugas pengumpul limbah medis tidak memakai Alat Pelindung Diri (APD), pengangkutan limbah medis menuju ke tempat pembuangan sementara menggunakan troli/gerobak terbuka, jalur yang digunakan adalah jalur umum yang biasa digunakan untuk pasien dan pengunjung rumah sakit, tidak ada label baik di tempat sampah maupun di troli. ${ }^{2}$

Penanganan limbah medis yang tidak dikelola dengan baik dapat menyebabkan infeksi nosokomial.Infeksi nosokomial (IN) disebut juga Hospital Acquired Infection atau Hospital Associated Infection adalah infeksi yang terjadi di rumah sakit, atau disebabkan oleh kuman yang didapat selama berada di rumah sakit. Kasus infeksi nosokomial atau infeksi yang terjadi ketika pasien dirawat di rumah sakit di seluruh dunia rata-rata sembilan persen dari 1,4 juta pasien rawat inap. Meski di Indonesia data akurat tentang angka kejadian infeksi nosokomial di rumah sakit belum ada, tetapi kasus ini menjadi masalah serius. ${ }^{4}$ Pasien yang mendapatkan infeksi nosokomial dapat melalui dirinya sendiri, petugas yang merawat di rumah sakit, pasien-pasien yang dirawat ditempat/ruangan yang sama rumah sakit tersebut, peralatan rumah sakit, peralatan makanan yang disediakan rumah sakit maupun yang didapatnya dari luar rumah sakit dan yang menjadi faktor penunjang untuk terjadinya infeksi nosokomial adalah faktor lingkungan, yang tergolong ke dalamnya adalah air, bahan yang harus dibuang atau limbah, dan udara. ${ }^{5}$

Petugas pengumpul limbah medis memiliki risiko tinggi terhadap infeksi nosokomial, dikarenakan bersentuhan langsung pada proses pengumpulan dan pengelolaan limbah tersebut. Menurut penelitian terdahulu yang dilakukan Muhamad Ardaris Alhudri Tahun 2012, terdapat 17 ruangan dari 23 ruang yang tidak memenuhi syarat dalam pemisahan sampah medis di Rumah Sakit Cut Meutia. Hal ini sangat berkaitan dengan pola perilaku petugas yang kurang memperhatikan aspek sanitasi lingkungan rumah sakit. ${ }^{6}$ 
Perilaku didasari oleh pengetahuan, kesadaran dan sikap dari individu.Apabila penerimaan perilaku didasari oleh kesadaran dan sikap yang positif maka perilaku tersebut bersikap langgeng (long lasting) dan begitu sebaliknya. ${ }^{7}$ Hal ini menyebabkan ada hubungan antara perilaku petugas dengan kejadian kasus nosokomial. Petugas pengumpul limbah harus dapat berperilaku sesuai dengan standar persyaratan kesehatan lingkungan rumah sakit yang berlaku. ${ }^{1}$

Berdasarkan survei data awal, Rumah Sakit Umum Cut Meutia setiap harinya menghasilkan produksi limbah medis sekitar 50 sampai 60 $\mathrm{kg} /$ hari.Penanganan limbah medis di Rumah Sakit Umum Cut Meutia dilakukan oleh petugas pengumpul/pengelolaan limbah medis. Berdasarkan observasi dan wawancara awal dengan petugas di Instalasi Pemeliharaan Sanitasi Lingkungan (IPSL) RSU Cut Meutia Kabupaten Aceh Utara, didapatkan data 23 ruangan yang menjadi sumber sampah medis rumah sakit, yaitu terdiri dari berbagai ruangan antara lain ruang Instalasi Gawat Darurat (IGD), ruang Operation Komer (OK), unit hemodialisa, ruang bersalin dan nifas, ruang paru, ruang anak, ruang rawat inap penyakit dalam pria dan wanita serta Intensive care unit (ICU).

Fasilitas pelayanan kesehatan tersebut tentunya menghasilkan seperti jarum suntik, kasa perban, kapas suntik, ampul, infusan, jaringan tubuh, sarung tangan dan masih banyak yang lainnya. Hasil limbah tersebut jika tidakditangani dengan serius mendatangkan risiko yang cukup berbahaya seperti terjadi infeksi pada karyawan maupun pasien dalam jangka waktu panjang. ${ }^{1}$ Berdasarkan hal tersebut maka peneliti ingin mengetahui hubungan pengetahuan, sikap dan ketersediaan fasilitas dengan praktik petugas pengumpul limbah medis di Rumah Sakit Umum Cut Meutia Kabubaten Aceh Utara tahun 2015.

\section{Metode Penelitian}

Penelitian ini merupakan penelitian deskriptif analitik dengan pendekatanpotong lintang (cross sectional study). Populasi dalam penelitian ini adalah seluruh petugas pengumpul limbah medis di Rumah Sakit Umum Cut Meutia yang berjumlah 35 orang, pengambilan sampel dilakukan secara total sampling. Pengambilan data dilakukan dengan menggunakan kuesioner.

\section{Hasil Penelitian \\ Analisis Univariat}

Analisis univariat dalam penelitian ini menggambarkan variabel usia, pendidikan, masa kerja, pengetahuan, sikap, fasilitas dan praktik yang disajikandalam bentuk tabel distribusi frekuensi dan persentase.

1. Distribusi usia petugas pengumpul limbah medis

Hasil penelitian dari 35 petugas pengumpul limbah medis di RSU CutMeutia Kabupaten Aceh Utara didapatkan data distribusi frekuensi usia seperti yang tertera pada tabel 1

Tabel 1. Distribusi usia petugas pengumpul limbah medis

\begin{tabular}{lcc}
\hline \multicolumn{1}{c}{ Usia } & Frekuensi & $\begin{array}{c}\text { Persentase } \\
\mathbf{( \% )}\end{array}$ \\
\hline 10-19 tahun & 1 & 2,9 \\
20-29 tahun & 15 & 42,9 \\
$30-39$ tahun & 14 & 40 \\
$40-49$ tahun & 4 & 11,4 \\
$\geq 50$ tahun & 1 & 2,9 \\
\hline Total & $\mathbf{3 5}$ & $\mathbf{1 0 0}$
\end{tabular}

Sumber: Data primer, 2015

Berdasarkan tabel 5.1 menunjukkan bahwa dari 35 petugas pengumpullimbah medis paling banyak usia 20-29 tahun yaitu 
sebanyak 15 orang $(42,9 \%)$ dan paling sedikit usia 10-19 tahun dan $\geq 50$ tahun yaitu masing-masing sebanyak 1 orang $(2,9 \%)$.

2. Distribusi pendidikan petugas pengumpul limbah medis

Hasil penelitian dari 35 petugas pengumpul limbah medis di RSU
CutMeutia Kabupaten Aceh Utara didapatkan data distribusi frekuensi pendidikanseperti yang tertera pada tabel 2 .

Tabel 2. Distribusi pendidikan petugas pengumpul limbah medis

\begin{tabular}{lcc}
\hline \multicolumn{1}{c}{ Pendidikan } & Frekuensi & Persentase (\%) \\
\hline Pendidikan tingkat dasar & 17 & 48,6 \\
Pendidikan tingkat menengah & 14 & 40 \\
Pendidikan tingkat tinggi & 4 & 11,4 \\
\hline Total & $\mathbf{3 5}$ & $\mathbf{1 0 0}$ \\
\hline
\end{tabular}

Sumber: Data primer, 2015

Berdasarkan tabel 5.2 menunjukkan bahwa dari 35 petugas pengumpullimbah medis paling banyak berada pada pendidikan tingkat dasar (tidak sekolah,SD dan SMP) yaitu sebanyak 17 orang $(48,6 \%)$ dan paling sedikit berada padapendidikan tingkat tinggi (Diploma dan S1) yaitu sebanyak 4 orang $(11,4 \%)$.

3. Distribusi masa kerja petugas pengumpul limbah medis

Hasil penelitian dari 35 petugas pengumpul limbah medis di RSU CutMeutia Kabupaten Aceh Utara didapatkan data distribusi frekuensi masa kerjaseperti yang tertera pada tabel 3 .

Tabel 3. Distribusi masa kerja petugas pengumpul limbah medis

\begin{tabular}{lcc}
\hline Masa Kerja & Frekuensi & $\begin{array}{c}\text { Persentase } \\
\mathbf{( \% )}\end{array}$ \\
\hline$\leq 1$ tahun & 8 & 22,9 \\
$1-5$ tahun & 21 & 60 \\
$6-10$ tahun & 5 & 14,3 \\
$\geq 10$ tahun & 1 & 2,9 \\
\hline Total & $\mathbf{3 5}$ & $\mathbf{1 0 0}$ \\
\hline
\end{tabular}

Sumber: Data primer, 2015

Berdasarkan tabel 5.3 menunjukkan bahwa dari 35 petugas pengumpullimbah medis paling banyak masa kerja 1-5 tahun yaitu sebanyak 21 orang (60\%)dan paling sedikit masa kerja $\geq 10$ tahun yaitu 1 orang $(2,9 \%)$.

4. Distribusi pengetahuan petugas pengumpul limbah medis

Hasil penelitian dari 35 petugas pengumpul limbah medis di RSU CutMeutia Kabupaten Aceh Utara didapatkan data distribusi frekuensi pengetahuanseperti yang tertera pada tabel 4.

Tabel 4 Distribusi pengetahuan petugas pengumpul limbah medis

\begin{tabular}{lcc}
\hline Pengetahuan & Frekuensi & $\begin{array}{c}\text { Persentase } \\
\mathbf{( \% )}\end{array}$ \\
\hline Kurang & 16 & 45,7 \\
Baik & 19 & 54,3 \\
\hline Total & $\mathbf{3 5}$ & $\mathbf{1 0 0}$ \\
\hline
\end{tabular}

Sumber: Data primer, 2015

Berdasarkan tabel 5.4 menunjukkan bahwa dari 35 petugas pengumpullimbah medis paling banyak memiliki pengetahuan kategori kurang yaitusebanyak 19 orang $(54,3 \%)$. 
5. Distribusi sikap petugas pengumpul limbah medis

Hasil penelitian dari 35 petugas pengumpul limbah medis di RSU CutMeutia Kabupaten Aceh Utara didapatkan data distribusi frekuensi sikap seperti yang tertera pada tabel 5 .

Tabel 5. Distribusi sikap petugas pengumpul limbah medis

\begin{tabular}{lcc}
\hline Pengetahuan & Frekuensi & $\begin{array}{c}\text { Persentase } \\
(\mathbf{\%})\end{array}$ \\
\hline Kurang & 18 & 51,4 \\
Baik & 17 & 8,6 \\
\hline Total & $\mathbf{3 5}$ & $\mathbf{1 0 0}$ \\
\hline
\end{tabular}

Berdasarkan tabel 5 menunjukkan bahwa dari 35 petugas pengumpullimbah medis paling banyak memiliki sikap kategori baik yaitu sebanyak 18 orang $(51,4 \%)$.

6. Distribusi ketersediaan fasilitas petugas pengumpul limbah

Hasil penelitian dari 35 petugas pengumpul limbah medis di RSU CutMeutia Kabupaten Aceh Utara didapatkan data distribusi frekuensi ketersediaanfasilitas seperti yang tertera pada tabel 6 .

Tabel 6. Distribusi ketersediaan fasilitas petugas pengumpul limbah

\begin{tabular}{lcc}
\hline \multicolumn{1}{c}{ Fasilitas } & Frekuensi & Persentase (\%) \\
\hline Tidak memenuhi Syarat & 14 & 40 \\
Memenuhi syarat & 21 & 60 \\
\hline Total & $\mathbf{3 5}$ & $\mathbf{1 0 0}$
\end{tabular}

Sumber: Data primer, 2015

Berdasarkan tabel 5.6 menunjukkan bahwa dari 35 petugas pengumpullimbah medis paling banyak memiliki fasilitas yang memenuhi syarat yaitusebanyak 21 orang $(60 \%)$.

7. Distribusi praktik petugas pengumpul limbah medis

Hasil penelitian dari 35 petugas pengumpul limbah medis di RSU CutMeutia Kabupaten Aceh Utara didapatkan data distribusi frekuensi praktik sepertiyang tertera pada tabel 7.

Tabel 7. Distribusi praktik petugas pengumpul limbah medis

\begin{tabular}{lcc}
\hline Praktik & Frekuensi & $\begin{array}{c}\text { Persentase } \\
\text { (\%) }\end{array}$ \\
\hline Kurang & 22 & 62,9 \\
Baik & 13 & 37,1 \\
\hline Total & $\mathbf{3 5}$ & $\mathbf{1 0 0}$ \\
\hline
\end{tabular}

Sumber: Data primer, 2015
Berdasarkan tabel 7 menunjukkan bahwa dari 35 petugas pengumpullimbah medis paling banyak memiliki praktik kategori kurang yaitu sebanyak 22orang $(62,9 \%)$.

\section{Analisis Bivariat}

Analisis bivariat dalam penelitian ini bertujuan untuk mengetahuihubungan pengetahuan, sikap dan ketersediaan fasilitas dengan praktik petugaspengumpul limbah medis. Uji statistik yang digunakan dalam analisis ini adalahuji Chi Square pada tingkat kepercayaan $95 \%(\alpha<0,05)$.

1. Hubungan pengetahuan dengan praktik petugas pengumpul limbah medis

Berdasarkan hasil pengelolaan data didapatkan hasil crosstabs antarapengetahuan dengan praktik pada tabel 8 . 
Tabel 8 Hubungan pengetahuan dengan praktik petugas pengumpul limbahmedis

\begin{tabular}{|c|c|c|c|c|c|c|c|}
\hline \multirow{3}{*}{ Pengetahuan } & \multicolumn{6}{|c|}{ Praktik } & \multirow{3}{*}{ P value } \\
\hline & \multicolumn{2}{|c|}{ Kurang } & \multicolumn{2}{|c|}{ Baik } & \multicolumn{2}{|c|}{ Total } & \\
\hline & $\mathbf{n}$ & $\%$ & $\mathbf{n}$ & $\%$ & $\mathbf{n}$ & $\%$ & \\
\hline Kurang & 14 & 73,7 & 5 & 26,3 & 19 & 100 & 0,274 \\
\hline Baik & 8 & 50 & 8 & 50 & 16 & 100 & \\
\hline Total & 22 & & 13 & & 35 & & \\
\hline
\end{tabular}

Sumber: Data primer, 2015

Berdasarkan tabel 8 dapat dilihat bahwa dari 35 orang petugaspengumpul limbah medis terdapat 19 petugas pengumpul limbah medis memilikipengetahuan dengan kategori kurang, 14 orang diantaranya memiliki praktikdengan kategori kurang dan 5 orang diantaranya memiliki praktik dengan kategoribaik. Petugas pengumpul limbah medis memiliki pengetahuan dengan kategoribaik berjumlah 16 orang, 8 orang diantaranya memiliki praktik dengan kategorikurang baik dan 8 orang diantaranya memiliki praktik dengan kategori baik. Hasiluji statistik Chi Square menunjukan $p$ value $0,274>$ a yang berarti Ho diterimaartinya tidak terdapat hubungan antara pengetahuan dengan praktik petugaspengumpul limbah medis di RSU Cut Meutia Kabupaten Aceh Utara bulanJanuari 2015 sampai Februari 2015.

2. Hubungan sikap dengan praktik petugas pengumpul limbah medis

Berdasarkan hasil pengelolaan data didapatkan hasil crosstabs antara sikap dengan praktik pada tabel 9

Tabel 9. Hubungan sikap dengan praktik petugas pengumpul limbah medis

\begin{tabular}{|c|c|c|c|c|c|c|c|}
\hline \multirow{3}{*}{ Sikap } & \multicolumn{6}{|c|}{ Praktik } & \multirow{3}{*}{ P value } \\
\hline & \multicolumn{2}{|c|}{ Kurang } & \multicolumn{2}{|c|}{ Baik } & \multicolumn{2}{|c|}{ Total } & \\
\hline & $\mathbf{n}$ & $\%$ & $\mathbf{n}$ & $\%$ & $\mathbf{n}$ & $\%$ & \\
\hline Kurang & 12 & 70,6 & 5 & 29,8 & 17 & 100 & \\
\hline Baik & 10 & 55,6 & 8 & 44,4 & 18 & 100 & 0,569 \\
\hline Total & 22 & & 13 & & 35 & & \\
\hline
\end{tabular}

Sumber: Data primer, 2015

Berdasarkan tabel 5.9 dapat dilihat bahwa dari 35 orang petugaspengumpul limbah medis terdapat 18 orang petugas pengumpul limbah medismemiliki sikap kategori baik, 10 orang diantaranya memiliki praktik dengankategori kurang dan 8 orang diantaranya memiliki praktik dengan kategori baik.Petugas pengumpul limbah medis memiliki sikap kategori kurang baik berjumlah17 orang, 12 orang diantaranya memiliki praktik dengan kategori kurang dan 5orang diantaranya memiliki praktik dengan kategori baik. Hasil uji statistik ChiSquare menunjukkan $\mathrm{p}$ value $0,569>$ a yang berarti Ho diterima artinya tidakterdapat hubungan antara sikap dengan praktik petugas pengumpul limbah medisdi RSU Cut Meutia Kabupaten Aceh Utara bulan Januari 2015 sampai Februari2015. 
3. Hubungan ketersediaan fasilitas dengan praktik petugas pengumpullimbah medis

Berdasarkan hasil pengelolaan data didapatkan hasil crosstabs antara ketersediaan fasilitas dengan praktik pada tabel 10

Tabel 10 Hubungan ketersediaan fasilitas dengan praktik petugas pengumpullimbah medis

\begin{tabular}{|c|c|c|c|c|c|c|c|}
\hline \multirow{3}{*}{ Fasilitas } & \multicolumn{6}{|c|}{ Praktik } & \multirow{3}{*}{$P$ value } \\
\hline & \multicolumn{2}{|c|}{ Kurang } & \multicolumn{2}{|c|}{ Baik } & \multicolumn{2}{|c|}{ Total } & \\
\hline & $\mathbf{n}$ & $\%$ & $\mathrm{n}$ & $\%$ & $\mathbf{n}$ & $\%$ & \\
\hline Tidak memenuhi syarat & 11 & 78,6 & 3 & 21,4 & 14 & 100 & \\
\hline Memenuhi syarat & 11 & 52,4 & 10 & 47,6 & 21 & 100 & 0,225 \\
\hline Total & 22 & & 13 & & 35 & & \\
\hline
\end{tabular}

Sumber: Data primer, 2015

Berdasarkan tabel 10 dapat dilihat bahwa dari 35 orang petugaspengumpul limbah medis terdapat 21 petugas pengumpul limbah medis memilikifasilitas yang memenuhi syarat, 11 orang diantaranya memiliki praktik dengankategori kurang dan 10 orang diantaranya memiliki praktik dengan kategori baik.Petugas pengumpul limbah medis memiliki fasilitas yang tidak memenuhi syaratberjumlah 14 orang, 11 orang diantaranya memiliki praktik dengan kategorikurang dan 3 orang diantaranya memiliki praktik dengan kategori baik. Hasil ujistatistik Chi Square menunjukan $\mathrm{p}$ value $0,225>$ a yang berarti Ho diterimaartinya tidak terdapat hubungan antara ketersediaan fasilitas dengan praktikpetugas pengumpul limbah medis di RSU Cut Meutia Kabupaten Aceh Utarabulan Januari 2015 sampai Februari 2015.

\section{PEMBAHASAN}

1. Hubungan Pengetahuan dengan Praktik Petugas Pengumpul Limbah Medis
Hasil penelitian menunjukan bahwa tidak adanya hubungan yangsignifikan antara pengetahuan dengan praktik petugas pengumpul limbah medis (pvalue 0,274 > a). Hal ini dapat disebabkan petugas pengumpul limbah medismemiliki pengetahuan baik dengan praktik kurang sebesar $50 \%$ dan pengetahuanbaik dengan praktik baik $50 \%$, artinya pengetahuan danpraktik tidak salingberpengaruh. Hal ini juga dapat disebabkan sebagian besar petugas pengumullimbah medis memiliki pengetahuan yang kurang $(54,3 \%)$ dan melakukan praktikyang kurang $(62,9 \%)$, sehingga petugas pengumpul limbah medis yang memilikipengetahuan dan praktik yang baik ditemukan relatif sedikit.

Hasil ini juga dapatdipengaruhi berdasarkan pengakuan sebagian responden bahwa sebagian besarpetugas pengumpul limbah medis belum pernah mendapatkan penyuluhan tentanglimbah medis. Penyuluhan dapat meningkatkan pengetahuan petugas pengumpullimbah medis. Pengetahuan dan praktik yang kurang baik oleh petugas pengumpullimbah 
medis dipengaruhi oleh pendidikan mereka. Hal ini dapat diketahui masihbanyak petugas pengumpul limbah medis memiliki pendidikan tingkat dasar(48,6\%) sehingga mempengaruhi pengetahuan mereka. Hasil penelitian ini sejalandengan yang dilakukan oleh Jasmawati (2012) yaitu tidak adanya hubungan yang signifikan antara pengetahuan dengan praktik petugas pengumpul limbah medis.Hasil penelitian ini berbeda dengan yang dilakukan oleh Heryani (2012) yaituterdapat hubungan yang signifikan antara pengetahuan dengan praktik petugaspengumpul limbah medis yang dilakukan di RSUD dr. M. Ashari Pemalang. ${ }^{8}$

Berdasarkan teori Mubarak dalam Muchsin (2013) menyatakan bahwasemakin tinggi pendidikan seseorang semakin mudah memperoleh informasisehingga semakin banyak pula pengetahuan yang dimiliki. ${ }^{9}$ Berdasarkan teori Notoatmodjo (2003) bahwa pendidikan adalah upaya persuasiatau pembelajaran kepada masyarakat agar masyarakat mau melakukan tindakantindakan(praktik) untuk memelihara (mengatasi masalahmasalah) danmeningkatkan kesehatan. Perubahan atau tindakan pemeliharaan dan peningkatankesehatan yang dihasilkan oleh pendidikan kesehatan ini didasarkan kepadapengetahuan dan kesadarannya melalui proses pembelajaran, sehingga melalui pendidikan petugas pengelola sampah (cleaning service)akan semakin mudah mendapatkan informasi dan pengetahuan terkait pengelolaanlimbah medis, terutama bahaya pencemaran terhadap kesehatan manusia. ${ }^{7}$

Pengetahuan merupakan kemampuan untuk membentuk model mentalyang menggambarkan objek yang tepat dan mempresentasikannya dalam aksiyang dilakukan terhadap suatu obyek. ${ }^{10}$ Teori pengetahuan dapat dibenarkan, dijamin kebenarannya ataumemiliki dasar yang dapat dipertanggung jawabkan secara nalar.11 Menurut Komang (2012), pengetahuan yang dimiliki tidak selalu menjadidasar dalam praktik, berdasarkan hal ini, pengetahuan yang baik tidak selalu menyebabkan seseorang berperilaku baik pula. ${ }^{12}$

2. Hubungan Sikap dengan Praktik Petugas Pengumpul Limbah Medis

Hasil penelitian menunjukan bahwa tidak adanya hubungan yangsignifikan antara sikap dengan praktik petugas pengumpul limbah medis ( $p$ value0,569 > a). Hal ini dapat disebabkan petugas pengumpul limbah medis memilikisikap baik dengan praktik kurang sebesar 55,6\% dan sikap baik dengan praktikbaik $44,4 \%$ (lebih rendah dari data sikap baik dengan praktik kurang sebesar55,6\%) sehingga sikap tidak berpengaruh terhadap praktik. Hal ini juga dapatdisebabkan dari pengetahuan petugas pengumpul limbah medis yang masihkurang (54,3\%) dimana sikap yang terbentuk tergantung pada pengetahuanseseorang, sehingga menyebabkan mereka kurang peduli terhadap pengelolaanmedis.

Hal ini sesuai dengan yang dikemukakan Suhartono dalam Iswari(2001) bahwa pengetahuan adalah sesuatu yang diperoleh secara biasa atau sehariharimelalui pengalaman, kesadaran dan informasi. Informasi ini dapat diperolehdari penyuluhan. ${ }^{13}$ Hasil penelitian ini sejalan dengan penelitian yangdilakukan oleh Jasmawati (2012) yaitu tidak adanya hubungan yang signifikanantara sikap dengan praktik petugas pengumpul limbah medis serta menyatakanbahwa semakin tinggi pengetahuan seseorang terhadap sesuatu, semakin baiksikap yang terbentuk. ${ }^{1}$ Hasil penelitian ini juga sejalan denganpenelitian yang dilakukan oleh Maria (2013) yaitu tidak adanya hubungan yangsignifikan antara sikap dengan praktik petugas pengumpul limbah medis.Sikap merupakan salah satu aspek psikologis 
individu yang sangat pentingsehingga sikap banyak mewarnai perilaku seseorang. Sikap setiap orangbervariasi, baik kualitas maupun jenisnya sehingga perilaku individu menjadibervariasi. ${ }^{14}$ Sikap adalah predisposisi atau kecenderunganyang dipelajari dari seseorang individu untuk merespon secara positif atau negative dengan intensitas yang moderat, memadai terhadap objek, situasi, konsep atauorang lain. Pembelajaran ini dapat diperoleh dari pendidikan seseorang. ${ }^{15}$ Berdasarkan teori Allport sikap terdiri dari 3komponen pokok, yaitu keyakinan, ide dan konsep terhadap objek, kehidupanemosional orang terhadap objek dan kecenderungan untuk bertindak (end tobehave). Ketiga komponen tersebut bersama-sama membentuk sikap yang utuh(total attitude), sehingga peranan pengetahuan, pikiran, keyakinan dan emosimemegang peranan penting dalam menentukan sikap yang utuh terhadaptimbulnya dampak seperti penyakit dan pencemaran lingkungan akibat limbahmedis. ${ }^{16}$ Sikap adalah respon tertutup seseorang terhadap suatu stimulus atau objek,baik yang bersifat intern maupun ekstern sehingga manifestasinya tidak dapatlangsung dilihat, tetapi hanya dapat ditafsirkan terlebih dahulu dari perilaku yangtertutup tersebut. Sikap secara realitas menunjukan adanya kesesuaian responterhadap stimulus tertentu. ${ }^{17}$

$$
\text { Tingkatan sikapMenurut }
$$

Notoatmodjo (2007) sikap terdiri dari beberapa tingkatan, yaitu: a). Menerima (receiving) diartikan bahwa seseorang atau subjek maumemperhatikan stimulus yang diberikan. b). Menanggapi (responding) diartikan memberi jawaban atau tanggapan terhadappertanyaan atau objek yang dihadapi. Memberikan jawaban apabila ditanya,mengerjakan dan menyelesaikan tugas yang diberikan adalah suatu indikasidari sikap. c). Menghargai (valuing) diartikan subjek atau seseorang memberikan nilai yangpositif terhadap objek atau stimulus. d). Bertanggung jawab (responsible), sikap yang paling tinggi tindakannya adalahbertanggung jawab terhadap yang telah diyakininya. Bertanggung jawab atassegala sesuatu yang telah dipilihnya dengan segala risiko merupakan sikapyang paling tinggi. ${ }^{7}$

3. Hubungan Ketersediaan Fasilitas dengan Praktik Petugas Pengumpul Limbah Medis

Hasil penelitian menunjukan bahwa tidak adanya hubungan yangsignifikan antara ketersediaan fasilitas dengan praktik petugas pengumpul limbahmedis ( $p$ value $0,225>$ a).Hal ini dapat disebabkan kurangnya kesadaranmemakai fasilitas yang telah disediakan, misalnya penggunaan APD.Hal inididukung dengan pengalaman pribadi yang selama bekerja tidak menggunakanAPD namun tidak mengalami gangguan pada saat bekerja dalam pengumpulanlimbah medis. Hal ini dapat dilihat, fasilitas untuk petugas pengumpul limbahmedis yang terdapat di RSU Cut Meutia telah memenuhi syarat, namun praktikpetugas pengumpul limbah medis masih dalam kategori kurang baik yaitu sebesar $52,4 \%$ petugas. Hal ini dapat juga disebabkan karena frekuensi penyuluhanmaupun sosialisasi tentang penggunaan APD masih rendah dan sebagian petugasmasih belum pernah mendapatkan penyuluhan.Hasil penelitian juga didapatkanmasih banyaknya tempat sampah yang kurang memadai, misalnya tempat sampahyang sudah rusak tapi masih dipergunakan.

Hal ini juga sesuai dengan penelitianBurhanuddin (2010) bahwa keberadaan tempat sampah limbah medis yang sudahdalam kondisi kurang memadai berpengaruh terhadap perilaku petugas dalampengumpulan sampah. ${ }^{18}$ Hasil penelitian ini juga sejalan dengan penelitian yangdilakukan oleh Jasmawati (2012) yaitu tidak adanya hubungan yang 
signifikanantara ketersediaan fasilitas dengan praktik petugas pengumpul limbah

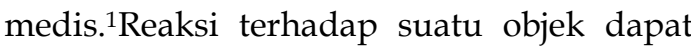
mempengaruhi suatu praktik seseorangyang dapat dipengaruhi oleh faktor pendukung yaitu fasilitas. Hal ini berdasarkandengan teori Notoatmojo dalam Yunita (2010) bahwa untuk mewujudkan sikapmenjadi suatu perbuatan yang nyata diperlukan faktor pendukung atau suatukondisi yang memungkinkan yaitu fasilitas. Sikap itu sendiri merupakan reaksiatau respon seseorang yang baik atau buruk terhadap suatu objek. ${ }^{15}$

Fasilitas kesehatan adalah fasilitas pelayanan kesehatan yang digunakanuntuk menyelenggarakan upaya pelayanan kesehatan perorangan, baik promotif,preventif, kuratif maupun rehabilitatif yang dilakukan oleh pemerintah,pemerintah daerah dan masyarakat. ${ }^{19}$ Beberapa fasilitas kesehatan diantaranya yaitu:

Alat Pelindung Diri (APD)

Tenaga kerja harus dilindungi dari berbagai masalah disekitarnya danpribadi, karena dapat mengganggu dirinya dan pelaksanaan pekerjaannya. ${ }^{20}$ Perlindungan tenaga kerja diperjelas dalam peraturan tujuh dari Control ofsubstances hazardous to health (COSHH) secara khusus menyatakan bahwapengendalian harus dilakukan melalui upaya-upaya selain penyediaan alatpelindung diri, tetapi jika upaya lain tidak dapat melindungi atau memberikanpengendaliaan yang cukup, disamping upaya itu, harus disediakan alatpelindungan diri yang sesuai secara memadai untuk mengendalikan pemajanan.Peraturan mengharuskan bahwa alat pelindung diri yang disediakan harus sesuaidengan tujuannya dan sesuai dengan standar yang disahkan oleh PejabatKesehatan dan Keselamatan. ${ }^{21}$

Peraturan Menteri Tenaga Kerja dan Transmigrasi Republik IndonesiaNomor PER.08/MEN/VII/2010 Tentang Alat
Pelindung Diri, Alat Pelindung Diridisingkat APD adalah suatu alat yang mempunyai kemampuan untuk melindungiseseorang yang fungsinya mengisolasi sebagian atau seluruh tubuh dari potensi bahaya di tempat kerja. Fungsi dan jenis alat pelindung diri: 22

a. Alat pelindung kepala: 1). Fungsi alat pelindung kepala untuk melindungi kepala dari benturan,terantuk, kejatuhan atau terpukul benda tajam atau benda keras yangmelayang atau meluncur di udara, terpapar oleh radiasi panas, api,percikan bahan-bahan kimia, jasad renik (mikroorganisme) dan suhu yang ekstrem. 2). Jenis alat pelindung kepala terdiri dari helm pengaman (safety helmet),topi atau tudung kepala, penutup atau pengaman rambut dan lain-lain

b. Alat pelindung mata dan muka: 1). Fungsi alat pelindung mata dan muka adalah melindungi mata dan mukadari paparan bahan kimia berbahaya, paparan partikelpartikel yangmelayang di udara dan di badan air, percikan benda-benda kecil, panas,atau uap panas, radiasi gelombang elektromagnetik yang mengion maupunyang tidak mengion, pancaran cahaya, benturan atau pukulan benda kerasatau benda tajam. Jenis alat pelindung mata dan muka terdiri dari kacamata pengaman(spectacles), goggles, tameng muka (face shield), masker selam dankacamata pengaman dalam kesatuan (full face masker).

c. Alat pelindung telinga: 1). Fungsi alat pelindung telinga adalah melindungi alat pendengaran terhadapkebisingan atau tekanan. 2). Jenis alat pelindung telinga terdiri dari sumbat telinga (ear plug) dan penutup telinga (ear muff)

d. Alat pelindung pernapasan beserta perlengkapannya: 1). Fungsi alat pelindung pernapasan beserta perlengkapannya adalahmelindungi organ pernapasan 
dengan cara menyalurkan udara bersih dansehat atau menyaring cemaran bahan kimia, mikroorganisme, partikelyang berupa debu, kabut (eerosoti, uap, asap, gas /fume) dan sebagainya. 2). Jenis alat pelindung pernapasan dan perlengkapannya terdiri dari masker, respirator, cartridge, canister, Re-breather, Airline respirator, ContinuesAir Supply Machine $=$ Air Hose Mask Respirator, tangki selam dan regulator (Self-Contained Underwater Breathing Apparatus/SCUBA), Self-Contained Breathing Apparatus (SCBA) dan emergency breathingapparatus

e. Alat pelindung tangan: 1). Fungsi alat pelindung tangan adalah melindungi tangan dan jari-jari tangandari pajanan api, suhu panas, suhu dingin, radiasi elektromagnetik, radiasimengion, arus listrik, bahan kimia, benturan, pukulan dan tergores,terinfeksi zat patogen (virus, dan bakteri) dan jasad renik. 2). Jenis pelindung tangan terdiri dari sarung tangan yang terbuat dari logam,kulit, kain kanvas, kain atau kain berpelapis, karet dan sarung tangan yangtahan bahan kimia

f. Alat pelindung kaki: 1). Fungsi alat pelindung kaki adalah melindungi kaki dari tertimpa atauberbenturan dengan bendabenda berat, tertusuk benda tajam, terkenacairan panas atau dingin, uap panas, terpajan suhu yang ekstrem, terkenabahan kimia berbahaya dan jasad renik, dan tergelincir. 2). Jenis pelindung kaki berupa sepatu keselamatan pada pekerjaan peleburan,pengecoran logam, industri, kontruksi bangunan, pekerjaan yangberpotensi bahaya peledakan, bahaya listrik, tempat kerja yang basah ataulicin, bahan kimia dan jasad renik, bahaya binatang dan lain-lain

g. Pakaian pelindung: 1). Fungsi pakaian pelindung adalah melindungi badan sebagian atau seluruhbagian badan dari bahaya suhu panas atau dingin yang ekstrem, pajananapi dan benda-benda panas, percikan bahan-bahan kimia, cairan dan logampanas, uap panas, benturan (impact) dengan mesin, peralatan dan bahan,tergores, radiasi, binatang, mikroorganisme patogen dari manusia, binatang, tumbuhan dan lingkungan seperti virus, bakteri dan jamurJenis pakaian pelindung terdiri dari rompi (Vests), celemek(Apron/Coveralls), jaket dan pakaian pelindung yang menutupi sebagianatau seluruh bagian badan

h. Alat pelindung jatuh perorangan: 1). Fungsi alat pelindung jatuh perorangan adalah membatasi gerak pekerjaagar tidak masuk ke tempat yang mempunyai potensi jatuh atau menjagapekerja berada pada posisi kerja yang diinginkan dalam keadaan miringmaupun tergantung dan menahan serta membatasi pekerja jatuh sehinggatidak terbentur lantai dasar. 2). Jenis alat pelindung jatuh perorangan terdiri dari sabuk pengaman tubuh(harness), karabiner, tali koneksi (lanyard), tali pengaman (safety rope),alat penjepit tali (rope clamp), alat penurun (decender), alat penahan jatuhbergerak (mobile fall arrester) dan lainlain

\section{Dampak Limbah Medis Terhadap Kesehatan Dan Lingkungan}

Limbah yang dipandang berbahaya dan dapat menimbulkan berbagai jenisdampak kesehatan sekitar 10-25\% dan sisanya merupakan limbah yang berasaldari instalasi kesehatan, limbah yang tidak mengandung risiko dan limbah"umum" yang menyerupai limbah rumah tangga sekitar 75-90\%. Limbah tersebutkebanyakan berasal dari aktifitas administrasi dan keseharian instalasi, di sampinglimbah yang dihasilkan selama pemeliharaan bangunan instalasi tersebut. ${ }^{23}$

Limbah padat yang dikumpulkan di suatu tempat penampungan dapat mencemari daratan.Tempat pengumpulan 
ini dapat bersifat sementara dan dapatpula bersifat tetap.Bentuk dampak pencemaran daratan tergantung padakomposisi limbah padat yang dibuang serta jumlahnya. Bentuk dampakpencemaran daratan dapat berupa: a). Dampak langsung, menimbulkan pemandangan yang tidak sedap, kotordan kumuh. Kesan kotor ini secara psikis akan mempengaruhi orang disekitartempat pembuangan tersebut. b). Dampak tidak langsung, salah satu contohnya menjadi tempatberkembangbiakan nyamuk, tikus, lalat dan lain-lain. Penyakit menularyang dapat ditimbulkan adalah penyakit pest, kaki gajah, malaria dan demamberdarah. ${ }^{24}$

Menurut Pruss (2005) limbah layanan kesehatan yang terdiri dari limbahcair dan limbah padat memiliki potensi yang mengakibatkan keterpajanan yangdapat mengakibatkan penyakit atau cedera. Sifat bahaya dari limbah layanankesehatan tersebut mungkin muncul akibat satu atau beberapa karakteristik berikut:

a. Limbah mengandung agen infeksius

b. Limbah bersifat genoktosik

c. Limbah mengandung zat kimia atau obat

- obatan berbahaya atau baracun

d. Limbah bersifat radioaktif

e. Limbah mengandung benda tajam

Semua orang yang terpajan limbah berbahaya dari fasilitas kesehatankemungkinan besar menjadi orang yang berisiko, termasuk yang berada dalamfasilitas penghasil limbah berbahaya, dan mereka yang berada diluar fasilitas sertamemiliki pekerjaan mengelola limbah semacam itu, atau yang berisiko akibatkecerobohan dalam sistem manajemen limbahnya. Kelompok utama yangberisiko, yaitu:a). Dokter, perawat, pegawai layanan kesehatan dan tenaga pemeliharaan rumahsakit, b). Pasien yang menjalani perawatan di instansi layanan kesehatan atau dirumah, c). Penjenguk pasien rawat inap, d). Tenaga bagian layanan pendukung yang bekerjasama dengan instansilayanan kesehatan masyarakat, misalnya, bagian binatu, pengelolaan limbah dan bagian transportas, e). Pegawai pada fasilitas pembuangan limbah (misalnya, ditempat penampungansampah akhir atau insinerator, termasuk pemulung. ${ }^{23}$

Salah satu contoh penyakit yang dapat timbul akibat pengelolaan limbah medis yang salah adalah infeksi nosokomial.Infeksi nosokomial dapat diartikansebagai infeksi yang diperoleh atau terjadi di rumah sakit.Menurut Darmadi (2008) suatu infeksi dikatakan didapat dari rumah sakitapabila memiliki ciri-ciri:a). Pada waktu penderita mulai dirawat di RS tidak mendapatkan tanda-tandaklinik dari infeksi tersebut, b). Pada waktu penderita mulai dirawat di RS tidak sedang masa inkubasi dariinfeksi tersebut, c). Tandatanda infeksi klinik tersebut timbul sekurang-kurangnya setelah $3 \times 24$ jam sejak mulai perawatan, d). Infeksi tersebut bukan merupakan sisa dari infeksi sebelumnya, e). Bila saat mulai dirawat di RS sudah ada tanda-tanda infeksi dan terbuktiinfeksi tersebut di dapat dari rumah sakit pada waktu yang sama pada waktuyang lalu.Faktor-faktor yang memberi peluang terjadinya infeksi nosokomial:a). Faktor yang ada pada diri penderita, b). Faktor keperawatan, c). Faktor mikroba pathogen. ${ }^{25}$

\section{KESIMPULAN}

Hasil penelitian tentang hubungan pengetahuan, sikap dan ketersediaan fasilitas dengan praktik petugas pengumpul limbah medis di Rumah Sakit UmumCut Meutia Kabupaten Aceh Utara tahun 2015 dapat disimpulkan sebagai berikut:

1. Tidak ada hubungan pengetahuan dengan praktik petugas pengumpullimbah medis di RSU Cut Meutia Kabupaten Aceh Utara ( $p$ value $0,274>0,05)$. 
2. Tidak ada hubungan sikap dengan praktik petugas pengumpul limbahmedis di RSU Cut Meutia Kabupaten Aceh Utara ( $p$ value 0,569 > $0,05)$.

3. Tidak ada hubungan ketersediaan fasilitas dengan praktik petugaspengumpul limbah medis di RSU Cut Meutia Kabupaten Aceh Utara (pvalue 0,225 > 0,05).

Saran

1. Bagi petugas pengumpul limbah medis diharapkan memanfaatkan fasilitasyang ada pada saat menangani limbah medis.

2. Bagi RSU Cut Meutia Kabupaten Aceh Utara diharapkan meningkatkanpengadaan fasilitasfasilitas yang diperlukan dalam pengelolaan limbahmedis seperti mengganti tempat sampah yang tidak memenuhi syarat.

3. Bagi dinas kesehatan kabupaten Aceh Utara diharapkan memberikanbimbingan dalam bentuk penyuluhan tentang pelaksanaan teknispengelolaan limbah.

\section{Daftar Pustaka}

1. Jasmawati., 2012. Hubungan Pengetahuan, Sikap, dan Ketersediaan Fasilitas dengan Praktik Petugas Limbah Medis Di RSUD Abdul Wahab Sjahranie Samarinda. Jurnal. Jurusan Kesehatan Masyarakat Universitas Hasanuddin. Makassar.

2. Keputusan Menteri Kesehatan RI. Nomor : :1204/Menkes/SK/X/2004 Tentang Persyaratan Kesehatan Lingkungan Rumah Sakit. Jakarta: Direktorat Penyehatan Lingkungan. http://www.hukor.depkes.go.id/.

3. Sunu, P., 2001. Melindungi Lingkungan dengan Menerapkan ISO 14001. Jakarta: PT Gramedia Widiasarana Indonesia. hal: 11

4. Dimyati, Vien., 2011. Infeksi RS Ancam Pasien. Jurnal Nasional Edisi 8
November

2011.

Jakarta.

www.jurnas.com.

5. Parhusip., 2005. Faktor-Faktor yang Mempengaruhi Terjadinya Infeksi Nosokomial Serta Pengendaliannya Di BHG.UPF.Paru Di RS Pirngadi/Lab. Penyakit Paru FK.USU Medan.Skripsi.Fakultas Kedokteran Bagian Ilmu Penyakit Paru Universitas Sumatera Utara. Medan

6. Alhudri, M.A., 2012. Gambaran Sistem Pengelolaan Sampah Medis di RSU Cut Meutia Kabupaten Aceh Utara Tahun 2011. Skripsi. Program Studi Pendidikan Dokter Universitas Malikussaleh. Aceh Utara.

7. Notoatmodjo, S., 2007. Promosi Kesehatan \& Ilmu Perilaku. Jakarta: Rineka Cipta. hal: 145, 147-148.

8. Heryani., 2012. Hubungan Tingkat Pengetahuan dan Sikap dengan Praktik Petugas Kebersihan Pengelola Sampah Medis Di RSUD dr. M. Ashari Pemalang. Skripsi. Jawa Tengah.

9. Muchsin., 2013. Gambaran Perilaku Perawat dalam Membuang Limbah Medis dan Non medis di Rumah Sakit Umum Daerah Kabupaten Aceh Tamiang Tahun 2013.Jurnal. Jurusan Kesehatan Masyarakat Universitas Sumatera Utara. Sumatera Utara.

10. Kusrini., 2006. Sistem Pakar Teori Aplikasi. Yogyakarta: ANDI. hal: 23, 24.

11. Sudarminta, J., 2010. Epistemologi Dasar. Yogyakarta: Kanisius. hal: 19.

12. Komang., 2012. Analisis Sistem Pengelolaan Limbah Medis Puskesmas Di Kabupaten Jember. Skripsi. Program Studi Kesehatan Masyarakat. Jember.

13. Iswari, Mari Sri., 2001. Pengetahuan Siswa Mengenai Narkotik dan Zat Aktif.Desember 2001.Jurnal. Penelitian Universitas Muhammadiah. Jakarta Selatan. Volume 7 No.4, hal 450.

14. Ali, M dan Asrori., 2011. Psikologi Remaja Perkembangan Peserta Didik. Jakarta: Bumi Aksara. 
15. Yunita., 2010. Efektifitas Metode Diskusi dan Ceramah terhadap Pengetahuan dan Sikap Perawat dalam Membuang Limbah Medis Padat di Puskesmas Kota Medan Tahun 2010.Tesis. Program Studi S2 Ilmu Kesehatan Masyarakat Universitas Sumatera Utara. Sumatera Utara.

16. Notoatmodjo, S., 2005. Metodologi Penelitian Kesehatan. Jakarta: Rineka Cipta

17. Sunaryo., 2004. Psikologi untuk Keperawatan. Jakarta: EGC. hal: 25-27.

18. Barhanuddin., 2010. Analisis Pengolahan Limbah Medis di Rumah Sakit yang Tidak Memenuhi Standar. Jurnal Kesehatan Lingkungan.

19. Peraturan Presiden RI No.12., 2013. Jaminan Kesehatan http://www.jkn.kemkes.go.id.

20. Dainiur.,1995. Materi-materi Pokok Ilmu Kesehatan Masyarakat. Jakarta: Widya Medika. hal: 77.
21. Harrington, J.M \& Gill, F.S., 2013. Buku Saku Kesehatan Kerja. Edisi 3. Jakarta: EGC. hal: 247.

22. Peraturan Menteri Tenaga Kerja Dan Transmigrasi Republik Indonesia Nomor PER.08/MEN/VII/2010 Tentang Alat Pelindung Diri. Alat Pelindung Diri disingkat APD.http://depnakertrans.go.id.

23. Pruss., 2005. Pengelolaan Aman Limbah Layanan Kesehatan. Jakarta: EGC. hal: 4, 21.

24. Wisnu., 2004. Dampak Pencemaran Lingkungan. Yogyakarta: ANDI. hal: 152

25. Darmadi., 2008. Infeksi Nasokomial: Problematika dan Pengendaliannya. Jakarta: Salemba Medika. hal: 2, 14-15. 